\title{
Plasma concentrations of prolactin in brushtail possums (Trichosurus vulpecula) in different physiological states
}

\author{
J L Crawford, B P Thomson, M F Beaumont and D C Eckery \\ Reproduction Group, AgResearch Ltd, Wallaceville Animal Research Centre, Ward Street, PO Box 40063, Upper Hutt, New Zealand \\ (Requests for offprints should be addressed to J L Crawford; Email: janet.crawford@agresearch.co.nz) \\ (D C Eckery is now at the School of Biological Sciences, Victoria University of Wellington, PO Box 600, Wellington, New Zealand)
}

\begin{abstract}
Prolactin (Prl) has been implicated in reproduction in many mammalian species and is illustrated by the distinctive patterns of secretion during the breeding season, the oestrous cycle and lactation. The recent development of a homologous RIA for measuring the circulating Prl concentrations in brushtail possums has facilitated the reliable measurement of $\operatorname{Prl}$ in plasma during different physiological states in this species for the first time. Determination of Prl concentrations during lactation involved the collection of weekly blood samples from eight female possums from the time of parturition through either one or two consecutive lactational cycles. Prl was at baseline levels during early lactation (weeks $0-14$ postpartum), and then increased markedly to maximum concentrations at weeks 19-21 before returning to nadir levels at a time coincident with the weaning of pouch young (weeks 2327). The profile of $\mathrm{Prl}$ secretion over the oestrous cycle and in particular at the time of the preovulatory LH surge was obtained from 14 possums during the reproductive cycle, in which preovulatory follicle development and ovulation were monitored by laparoscopy. There was no distinct daily pattern
\end{abstract}

of Prl secretion during the oestrous cycle; however, in 3/4 possums in which a typical preovulatory LH surge was measured, a biphasic preovulatory Prl surge was also observed. The preovulatory Prl surge commenced $2-6 \mathrm{~h}$ prior to, and had returned to baseline close to the onset of, the preovulatory LH surge, and a second surge of Prl occurred concomitantly with the delayed preovulatory FSH surge. Seasonality of Prl levels was established from weekly blood samples collected from six barren female possums, and concentrations of $\mathrm{Prl}$ were lower during the breeding season compared to the nonbreeding season. Additionally, a circadian pattern of $\operatorname{Prl}$ secretion was evident in both female and male possums, with Prl levels higher in the morning compared to the afternoon. In conclusion, interpretation of endogenous secretory patterns suggests that Prl may be important during late lactation and at impending ovulation, but the involvement of the circannual rhythm of Prl in the regulation of seasonality in the brushtail possum remains to be determined.

Journal of Endocrinology (2006) 190, 295-305

\section{Introduction}

Prolactin (Prl) has been reported to play a role in reproduction, in particular ovarian function, and lactation in many mammalian species (for reviews, see Sinha 1995, Freeman et al. 2000). However, it was not until the recent production of Prl-related knockout (KO) mice models (Thomas \& Capecchi 1987) that it was established that Prl does indeed play a fundamental role in both reproductive and lactational processes. A decline in ovulation rate, reduced fertilisation, almost complete arrest of preimplantation development and implantation failure of the uterus culminates in complete sterility in $\mathrm{Prl}$ receptor homozygous $\mathrm{KO}$ female mice (PRLR ${ }^{-1-}$ ) (Bole-Feysot et al. 1998). In the male, Prl has been implicated in testosterone production by Leydig cells (Kelly et al. 1991), sperm capacitation (Shah \& Sheth 1979) and function of accessory reproductive glands
(Bartke 1980, Costello \& Franklin 1994), but surprisingly, $\mathrm{PRLR}^{-/-}$male mice are fully fertile although puberty is delayed (Bole-Feysot et al. 1998).

$\mathrm{Prl}$ is involved in maintenance of the corpus luteum (CL) by stimulating the expression of both oestrogen and luteinising hormone (LH) receptors (Gibori 1993) and by suppressing the activity of $20 \alpha$-hydroxysteroid dehydrogenase, thereby inhibiting progesterone $\left(\mathrm{P}_{4}\right)$ catabolism to an inactive steroid (Albarracin et al. 1994, Telleria et al. 1997) in rats. Prl has also been implicated in both parturition (Hearn 1974) and maintenance of embryonic diapause (Hearn 1974, Curlewis et al. 1986) in several marsupial macropodid species, thereby suggesting a role in luteal function in marsupials. The widespread expression of Prl receptor mRNA (L Haydon \& DC Eckery, unpublished observations) in those ovarian cell types that also express mRNA for steroid acute regulatory protein, P450 side-chain cleavage, $3 \beta$-hydroxysteroid 
dehydrogenase, and P450 aromatase (Eckery et al. 2002, Whale et al. 2003) in the brushtail possum implies that Prl plays a significant role in ovarian function and in particular steroidogenesis in this species. The recent development of a homologous Prl RIA for measuring Prl in brushtail possums (Crawford et al. 2005) has enabled the endogenous secretory patterns of Prl during lactation, the oestrous cycle and throughout the breeding and non-breeding seasons to be elucidated for the first time in this species.

\section{Materials and Methods}

\section{Animals and management}

Possums were live-captured in the Wellington (latitude $41^{\circ} \mathrm{S}$ ) region of New Zealand. At the time of capture, each animal was screened for health status and only apparently healthy animals were included in this study. Animals were housed in the AgResearch Wallaceville possum facility under a group housing system (McLeod et al. 1997). A mixed diet of fresh fruits and vegetables, bread and cereal-based pellets was provided along with selective browsing of Pinus radiata branches. Fresh water was always available.

All experimental procedures were approved by the AgResearch Wallaceville Animal Ethics Committee in accordance with the Animal Welfare Act of NZ, 1987.

\section{Hormonal profiles during lactation}

To determine the endogenous secretory patterns of reproductive hormones during lactation, groups of three reproductively cycling adult female possums and one adult male possum were housed together as breeding groups. In March 2003, pouches of eight female possums $(3 \cdot 25 \pm 0 \cdot 11 \mathrm{~kg}$ bodyweight $)$ were checked daily for confirmation of the exact day of parturition. Blood samples were collected via jugular venepuncture from anaesthetised possums (induced and maintained by inhalation of a gaseous mixture of oxygen:isofluane; ICI Pharmaceuticals, Cheshire, UK) on the day of parturition, then weekly thereafter until either removal of a joey or natural weaning (19-31 weeks). In four of these animals, weekly blood samples were continued for a second consecutive lactational cycle (1327 weeks). Joeys that displayed signs of ill health were immediately excluded from the study.

\section{Hormonal profiles during the oestrous cycle}

To determine the endogenous secretory patterns of reproductive hormones over an oestrous cycle, particularly at the time of impending ovulation, 20 adult female possums with joeys were divided into two replicates (for logistical purposes). This experiment was completed in one breeding season (2003). For the collection of blood samples, an indwelling catheter was inserted surgically in the jugular vein (Curlewis et al. 1985) of anaesthetised possums (Zoletil
100; Virbac, Techvet Laboratories, Auckland, New Zealand). Blood samples were taken daily by jugular venepuncture from anaesthetised (isofluane) possums when the catheter failed. During the intensive (hourly) blood sampling period, packed cell volume was monitored every $4 \mathrm{~h}$ and red blood cells (resuspended in sterile saline at $37^{\circ} \mathrm{C}$ ) were replaced via the catheter after each sample was collected. No individual haematocrit value dropped below $82 \%$ of the initial value at any time during the sampling period. Repeated laparoscopic examination of the ovaries was carried out at infrequent intervals ( $2-4$ days) in anaesthetised (isofluane) possums to monitor follicle development (Crawford et al. 1997). Not more than four laparoscopic examinations were performed on any individual animal. All joeys were removed and rendered unconscious either by immersion in ice water to induce hypothermia ( $<60$ days old cannot regulate body temperature) or isofluane ( $\geq 60$ days old) before being killed by decapitation.

Replicate 1 A group of ten possums $(2 \cdot 86 \pm 0 \cdot 10 \mathrm{~kg})$ with indwelling catheters had pouch young removed (RPY) (estimated age ranging from 18-47 days) in mid-breeding season (May). Daily blood samples were collected from -4 to 23 days after RPY. Laparoscopic examinations were carried out at infrequent intervals from 6 days after RPY until the observed day of ovulation (presence of a stigma point on the preovulatory follicle). Blood samples were collected at hourly intervals for $48 \mathrm{~h}$ in individual animals in which the presumptive preovulatory follicle appeared to be within $48 \mathrm{~h}$ of ovulation (Crawford et al. 1997).

Replicate 2 A group of ten possums $(2 \cdot 86 \pm 0 \cdot 14 \mathrm{~kg})$ with indwelling catheters had RPY (estimated age ranging from 27-115 days) in the late breeding season (August). Daily blood samples were collected from -2 to 34 days post-RPY. Seven days after RPY, laparoscopic examination of ovaries and consequent intensive (hourly) blood sampling regimes of individual animals commenced as described earlier.

Additionally, the plasma samples from one possum, in which a preovulatory LH surge was captured in an intensive blood sampling window from an identical experiment carried out at AgResearch Invermay in 1997, was included in this study.

Hormonal profiles during the breeding and non-breeding seasons

To determine endogenous secretory patterns of reproductive hormones over an entire breeding and non-breeding season, six barren adult female brushtail possums were divided into two groups and each group was housed with a vasectomised male possum. Vasectomies were carried out under general anaesthetic (Zoletil 100), although, as a precaution, local anaesthetic (Lignocaine hydrochloride BP 2\%; Ethical Agents Ltd, Auckland, New Zealand) was also administered s.c. at the two incision sites. An injection (i.m.) of antibiotic 
(Streptopen; A/S Rosco, Denmark; Bomac Laboratories Ltd, Auckland, New Zealand) was given as a prophylactic measure against infection. A small incision was made on one side of the scrotum using aseptic techniques and the vas deferens was located, cut and the ends ligated. The incision site was closed and the procedure was repeated on the other side.

The blood samples were collected via jugular venepuncture from anaesthetised (isofluane) female possums at weekly intervals from March 2004 to May 2005. Reproductive cyclicity was monitored in individual possums at daily intervals by analysis of urine for cytology (Curlewis et al. 1985, Duckworth et al. 1998).

\section{Circadian hormonal profiles}

Changes in endogenous circadian secretory patterns of Prl were determined in female possums in the mid-late follicular phase and reproductively active male possums. Blood samples were collected at $0800 \mathrm{~h}$ and $1700-2000 \mathrm{~h}$ for either 2 $(n=11)$ or $3(n=8)$ consecutive days in males and $3(n=14)$ consecutive days in females. The blood samples were collected either via jugular venepuncture under anaesthesia (isofluane) or an indwelling jugular cannula in July 2004 (males) and May-July 2003 (females).

\section{Hormone RIA}

Plasma concentrations of $\mathrm{LH}$ and follicle-stimulating hormone (FSH) were measured by heterologous RIA using procedures described previously for the possum (Moore et al. $1997 a, b)$. Within this study, the limits of detection $(80 \%$ of zero binding) were 0.2 and $0.5 \mathrm{ng} / \mathrm{ml}$ for $\mathrm{LH}$ and $\mathrm{FSH}$ respectively. The intra- and interassay coefficients of variation $(\mathrm{CV})$ for LH RIA were $<12.5$ and $<10.3 \%$ respectively. The intra- and interassay CV values for FSH RIA were $<11 \cdot 7$ and $<8 \cdot 1 \%$ respectively.

Plasma Prl concentrations were measured by homologous RIA using a previously described method (Crawford et al. 2005). Within this study, the limit of detection of the assay was $0.2 \mathrm{ng} / \mathrm{ml}$, and the intra- and interassay CV values were $<11.5$ and $<14.1 \%$ respectively.

Plasma $\mathrm{P}_{4}$ levels were measured by direct RIA as described previously (Crawford et al. 1997). The limit of detection was $0.5 \mathrm{ng} / \mathrm{ml}$, and the intra- and interassay $\mathrm{CV}$ values were $<11.9$ and $<9 \%$ respectively.

\section{Statistical analyses}

Plasma Prl, $\mathrm{LH}, \mathrm{FSH}$ and $\mathrm{P}_{4}$ concentrations over one or two consecutive lactational cycles and during the oestrous cycle in female possums, and plasma Prl concentrations in the morning and afternoon in female and male possums, were log-transformed prior to analysis using a one-way ANOVA. Weekly plasma Prl, LH, FSH and $\mathrm{P}_{4}$ concentrations over 15 months in female possums were log-transformed prior to analysis using two-way ANOVA. Differences over time were calculated by an unbalanced design using Genstat regression.

\section{Results}

\section{Hormonal profiles during lactation}

The profiles of mean plasma Prl, LH and FSH concentrations were similar in the first and second consecutive lactation cycles (Fig. 1). Mean Prl levels were generally basal from 0 to $\sim 14$ weeks post-partum, when pouch young lacked fur and were mostly confined to the pouch. The intermittent exit of the furred young from the pouch after approximately 12-16 weeks of age was coincident with an initial rise $(P<0 \cdot 01)$ in plasma Prl concentrations. Mean Prl concentrations peaked at 19-21 weeks post-partum, when pouch young were observed to reside permanently outside the pouch and ride on the back of the adult. Plasma Prl concentrations declined $(P<0 \cdot 01)$ thereafter, and reached basal levels at 23-27 weeks postpartum coincident with the observed regression of the mammary glands and weaning. Mean weekly plasma LH concentrations were at basal levels throughout the first and second consecutive lactation cycles (Fig. 1). Similarly, mean weekly plasma FSH concentrations did not change significantly during lactation (Fig. 1).

Representative profiles of plasma Prl, LH, FSH and $\mathrm{P}_{4}$ concentrations in individual possums over one or two consecutive lactational cycles are illustrated in Fig. 2. Possums with pouch young, which were weaned naturally (Fig. 2a and c, first cycle; Fig. 2d, second cycle) or became ill and either died or were euthanised at the time of normal weaning

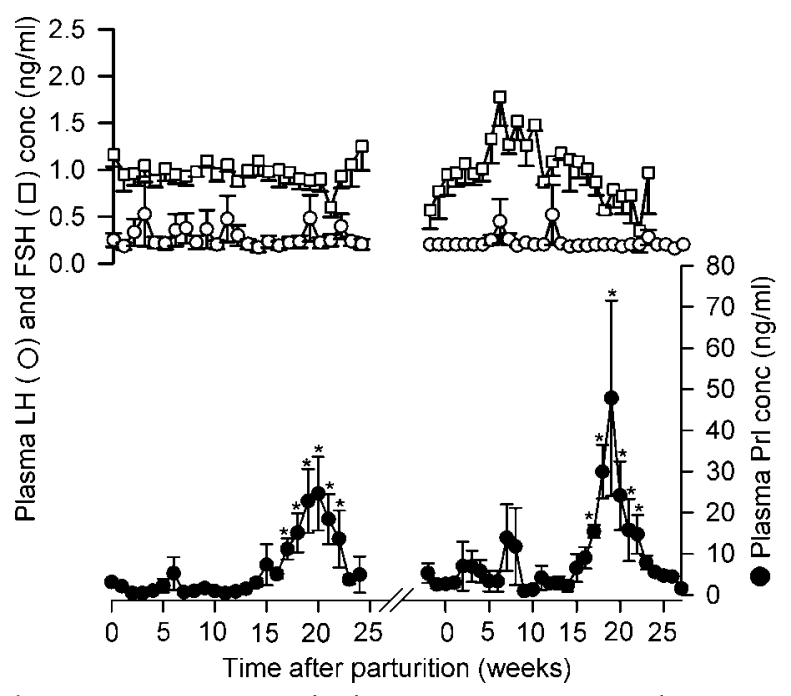

Figure 1 Mean maternal plasma concentrations of ( $\mathrm{LH} \mathrm{O}$ ), (FSH $\square$ ) and prolactin ( $\mathrm{Prl} \bullet$ ) in relation to time after parturition in female brushtail possums with healthy suckling pouch young over one $(n=8)$ or two consecutive $(n=3)$ lactational cycles. Values are depicted as means \pm S.E.M. Asterisks denote values that are significantly different $(P<0 \cdot 05)$. 

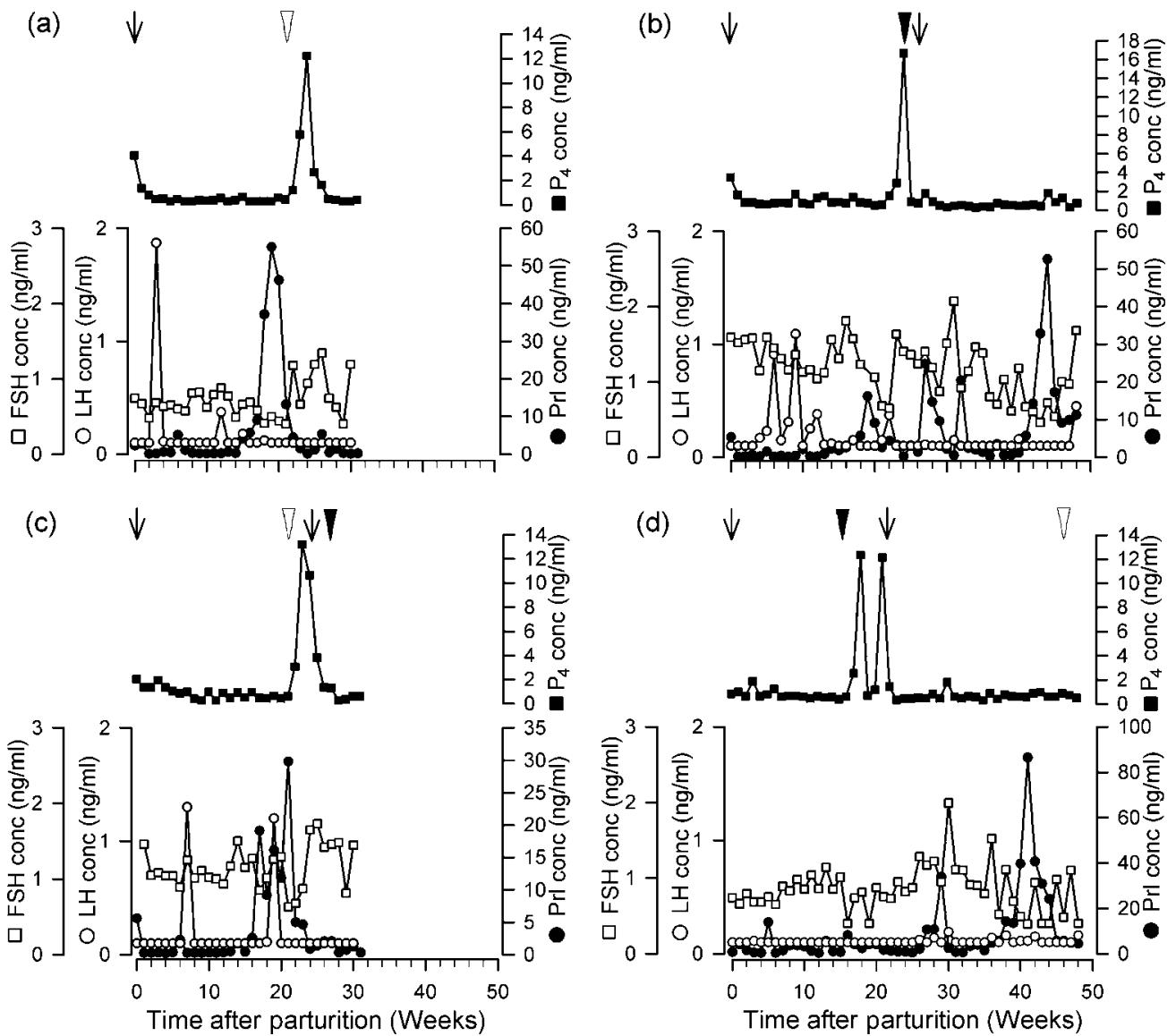

Figure 2 Representative maternal plasma profiles of $\mathrm{LH}(\mathrm{O}), \mathrm{FSH}(\square), \operatorname{Prl}(\boldsymbol{O})$ and progesterone $\left(\mathrm{P}_{4} ; \mathbf{\square}\right)$ in relation to time after parturition in individual female brushtail possums over one (a and c) or two consecutive (b and d) lactational cycles. Arrows depict the birth of pouch young and arrowheads represent the termination of suckling by pouch young due to either weaning (open) or removal due to illness or death (closed). Note that weeks $0-33$ are during the breeding season and weeks $\sim 33-49$ are during the non-breeding season.

(Fig. 2b, first cycle), had a normal secretory pattern of $\operatorname{Prl}$ (cf. Fig. 1) and ovulated either during or after elevated $\mathrm{P}_{4}$ plasma concentrations (Fig. 2). However, Prl concentrations remained low throughout lactation in animals that had pouch young in ill-health that either died, or were euthanised, prior to natural weaning (Fig. 2c, second cycle; Fig. 2d, first cycle). Animals with pouch young that died prematurely in the breeding season ovulated thereafter as represented by high $\mathrm{P}_{4}$ levels (Fig. 2d, first cycle). There was no distinct pattern of plasma LH or FSH secretion in individual lactating possums; however, plasma FSH concentrations declined $(P<0 \cdot 05)$ prior to a marked and sustained increase in plasma $\mathrm{P}_{4}$ levels (Fig. 2).

\section{Hormonal profiles over the oestrous cycle}

Fourteen possums that had RPY were observed by laparoscopic examination to develop a preovulatory follicle, which progressed to ovulation, while the other five possums remained anoestrus. The daily pattern of mean plasma Prl,
$\mathrm{LH}, \mathrm{FSH}$ and $\mathrm{P}_{4}$ concentrations over an oestrous cycle was similar in animals in Replicate 1 (Fig. 3a) and Replicate 2 (Fig. 3b). There was no distinct pattern in mean Prl levels during the follicular phase of the oestrous cycle. Mean Prl concentrations were lower $(P<0 \cdot 05)$ on days $1-6$ postovulation than those observed on 17-22 days post-ovulation. The between-animal variation was large in both the replicates.

Mean LH concentrations were at baseline throughout the sampling period, except on the day of ovulation (day 0 ), when LH concentrations had increased $(P<0 \cdot 05)$. On the day of ovulation, the between-animal variation was large for both the replicates.

From 12 days prior to ovulation, mean FSH concentrations continuously declined $(P<0 \cdot 01)$ to nadir levels during the late follicular phase. An increase $(P<0 \cdot 01)$ in FSH concentrations was observed on the day of ovulation. Mean FSH concentrations were higher $(P<0 \cdot 05)$ from days 3 to 18 post-ovulation in possums, compared to those in the late follicular stage ( -4 to -1 days post-ovulation). Due to the 

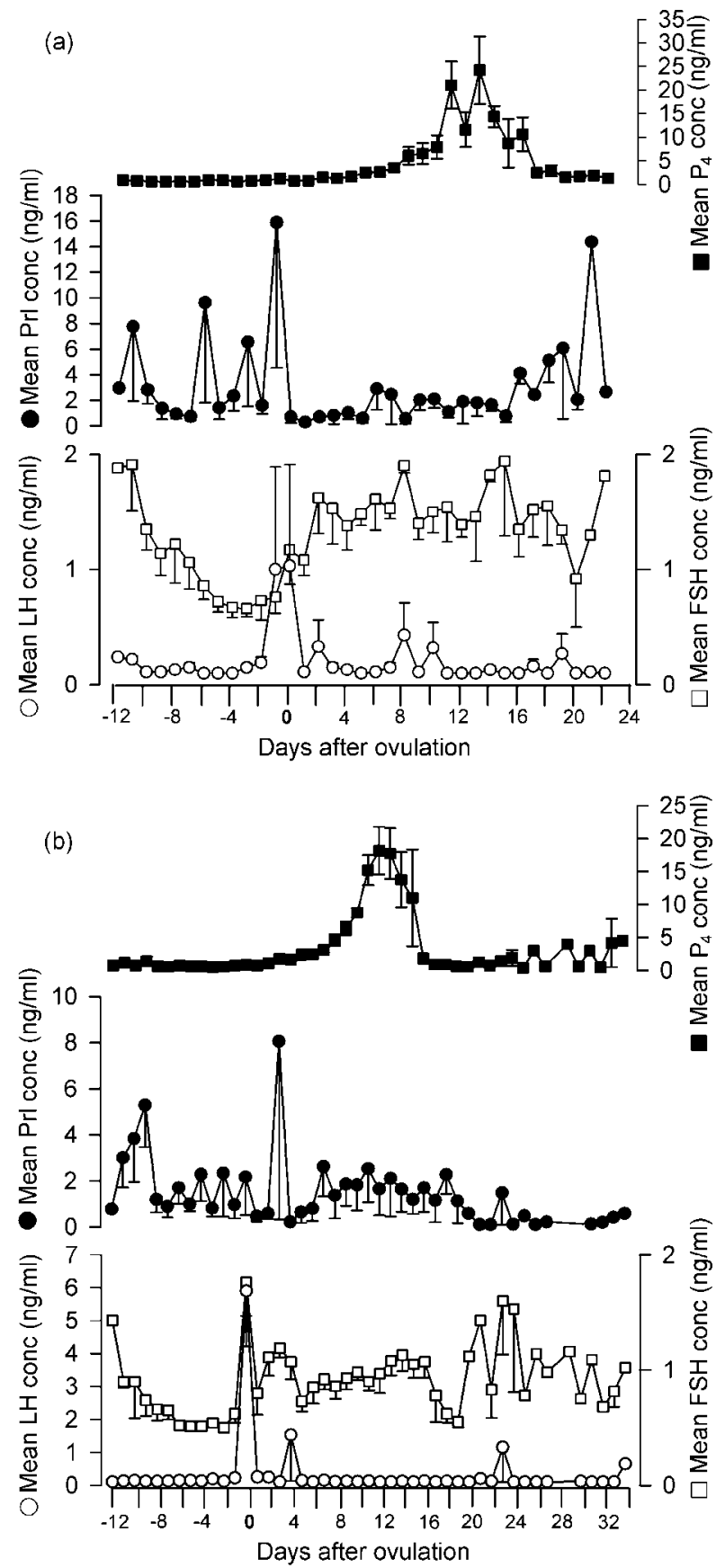

Figure 3 Mean daily plasma concentrations of $\mathrm{LH}(\mathrm{O}), \mathrm{FSH}(\square)$, $\mathrm{Prl}(\mathbf{O})$ and $\mathrm{P}_{4}(\mathbf{\square})$ in reproductively cycling female brushtail possums in relation to the day of ovulation. For the logistics of this study, the animals were allocated into either Replicate $1(\mathrm{a} ; n=8)$ or Replicate $2(b ; n=6)$. Note that blood sampling was continued for 10 days longer in some animals in Replicate 2 compared to those in Replicate 1. Values are denoted as means \pm S.E.M. longer sampling period in Replicate 2 animals, mean FSH concentrations continuously declined from 16 to 19 days post-ovulation depicting the progression of these animals into the next follicular phase.

Mean $\mathrm{P}_{4}$ levels were at baseline throughout the follicular phase of the oestrous cycle. The concentrations increased significantly $(P<0 \cdot 01)$ by day 9 post-ovulation, peaked at 13-14 days post-ovulation and returned to nadir levels by 15-17 days post-ovulation.

\section{Hormonal profiles during the peri-ovulatory period}

Representative hourly profiles of plasma LH, FSH and Prl concentrations in individual possums are illustrated in Fig. $4 \mathrm{a}-\mathrm{i}$. The hormonal profiles varied markedly between the eight possums in which the intensive blood-sampling window was completed 1-4 days prior to the observed day of ovulation (stigma observed on the preovulatory follicle). Four of these animals had basal LH concentrations, low FSH concentrations and either high- (Fig. 4a) or low-amplitude (Fig. 4b) fluctuations in the concentrations of Prl. The remaining four possums had basal plasma levels for all three hormones (Fig. 4c). A preovulatory LH surge was measured, within the intensive blood-sampling window, in four possums in this study and in one possum from an identical experiment undertaken at AgResearch Invermay, where possums were sampled near the day of ovulation. In these five possums, a surge $(5-8 \mathrm{~h}$ in duration) of plasma LH and a coincident, but slightly delayed surge (6-9 h in duration) of FSH, were observed (Fig. 4d-h). In three of these five animals, a surge (3-5 h in duration) of $\mathrm{Prl}$ was also observed $2-6 \mathrm{~h}$ before the preovulatory LH surge and a second Prl surge (5-9 h in duration) occurred coincidently with the delayed preovulatory FSH surge (Fig. $4 \mathrm{~d}-\mathrm{f}$ ). In the remaining two possums, plasma $\mathrm{Prl}$ remained at basal levels (Fig. $4 \mathrm{~g}$ and $\mathrm{h}$ ) and one of these animals exhibited two LH and FSH surges that were $12 \mathrm{~h}$ apart (Fig. 4h). Plasma Prl concentrations were baseline during this $48 \mathrm{~h}$ window in these five animals, excluding the time of preovulatory Prl surge. In two possums, the intensive blood-sampling window was initiated one day after the day of ovulation. In these animals, the plasma concentrations of $\mathrm{LH}$ were low and of $\mathrm{Prl}$ were variable, whereas those of FSH increased gradually over time (Fig. 4i).

Hormonal profiles during the breeding and non-breeding seasons

Weekly profiles of plasma $\mathrm{P}_{4}, \mathrm{LH}, \mathrm{FSH}$ and $\mathrm{Prl}$ concentrations in six individual possums over a 15 -month period are illustrated in Fig. 5. Analysis of these results included the data from March to October (entire breeding season 2004), December to February (entire non-breeding season 20042005) and April to May (partial breeding season 2005). Data outside these months were considered to be in the transition time between the breeding and non-breeding seasons and thus were excluded from the analysis. The overall timing of the breeding and non-breeding seasons in individual 


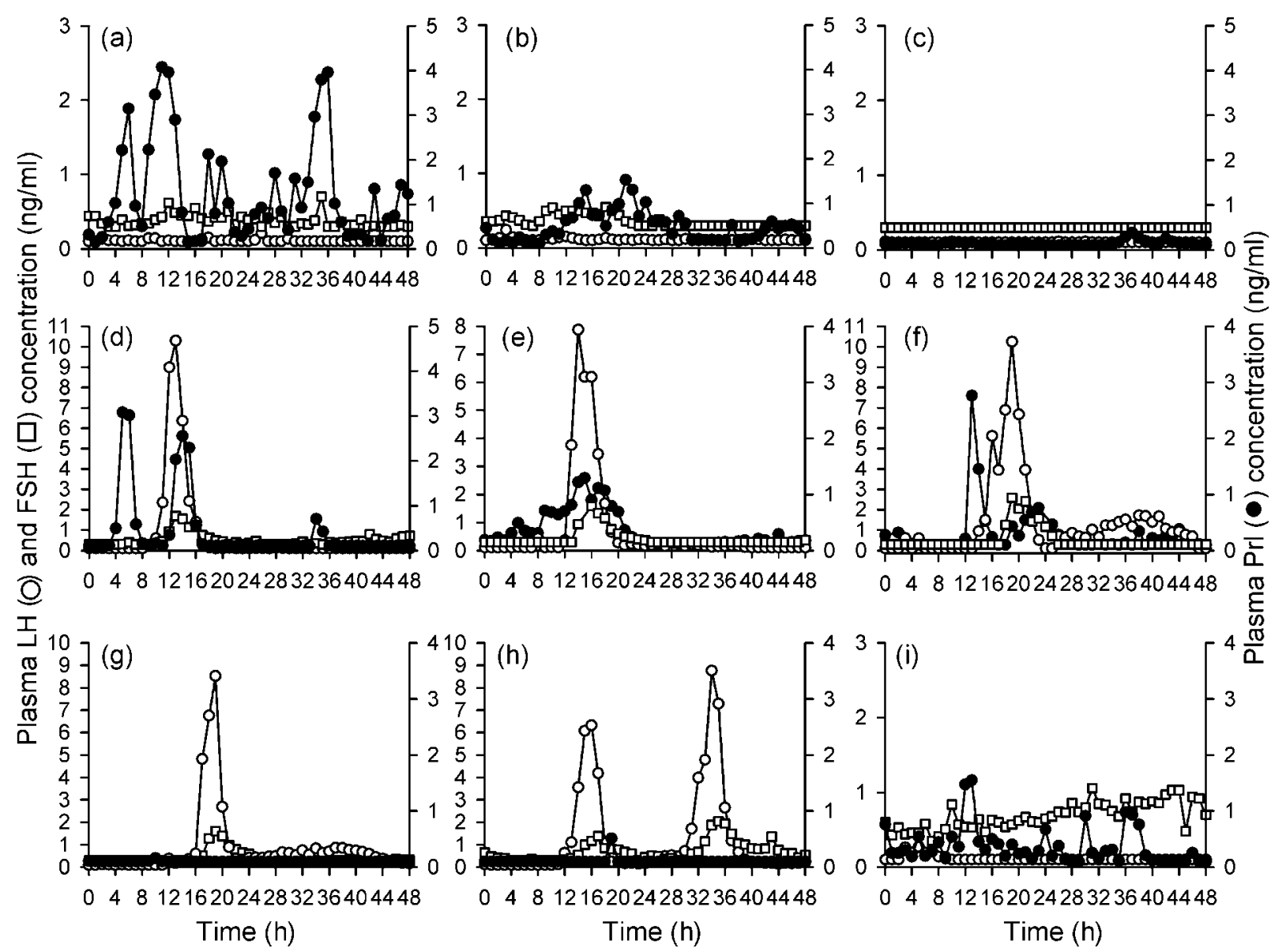

Figure 4 Representative profiles of plasma concentrations of $\mathrm{LH}(\mathrm{O}), \mathrm{FSH}(\square)$ and $\operatorname{Prl}(\mathbf{O})$ in individual adult female brushtail possums at (a)-(c) 1-4 days prior to ovulation, (d)-(h) near the time of ovulation and incorporating the preovulatory surges and (i) 1-2 days after ovulation. Note the abnormal double surge of LH and FSH in one animal (h).

possums was confirmed by the presence or absence of episodic elevations in $\mathrm{P}_{4}$ concentrations respectively (Fig. 5a). The majority of the peaks of $\mathrm{P}_{4}$ concentrations were preceded (1-2 weeks) by a significant influx in the numbers of epithelial cells within the urine of these possums. Plasma LH levels were usually at basal levels in all animals, although infrequent elevations in LH concentrations were detected (Fig. 5b). Both plasma FSH and Prl concentrations fluctuated markedly throughout the breeding and non-breeding seasons in all animals (Fig. $5 \mathrm{c}$ and d). Despite wide animal variation, mean plasma concentrations of Prl were lower $(P<0 \cdot 05)$ and FSH were higher $(P<0 \cdot 05)$ in the breeding season compared with the non-breeding season. There were no evident seasonal changes in mean weekly plasma LH levels.

\section{Circadian hormonal profiles during the breeding season}

Mean plasma Prl concentrations in both female and male possums were significantly higher $(P<0 \cdot 01)$ at $0800 \mathrm{~h}$ compared to that at 1700-2000 h (Fig. 6). The elevation of plasma Prl concentrations in the morning, compared to the afternoon, was also evident in individual possums that had blood samples collected at intensive intervals near, but not at the time of the preovulatory LH surge (Fig. $4 \mathrm{a}$ and i; $0800 \mathrm{~h}$ sample corresponded to time 13 and 37 h; Fig. $4 \mathrm{~b} ; 0800 \mathrm{~h}$ sample corresponded to time 21 and $45 \mathrm{~h}$ ). Mean plasma LH concentrations remained low regardless of the time of blood collection (data not shown).

\section{Discussion}

We report, for the first time, the endogenous secretory patterns of $\mathrm{Prl}$ in female brushtail possums during lactation, the oestrous cycle and the breeding and non-breeding seasons, as well as the circadian changes in $\mathrm{Prl}$ in female and male brushtail possums.

There was a distinct pattern of Prl concentrations during lactation in the possum in this study, which was similar, but not identical to that previously reported for possums (Hinds \& Janssens 1986) and other (Curlewis et al. 1986, Hinds \& Merchant 1986, Muths \& Hinds 1996) marsupial species. 
(a) $\mathrm{P}_{4}$

(b) $\mathrm{LH}$

(c) $\mathrm{FSH}$
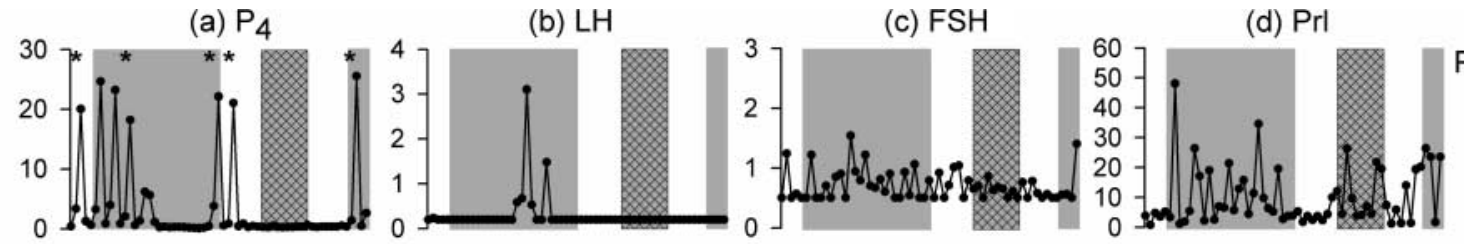

Possum

(i)
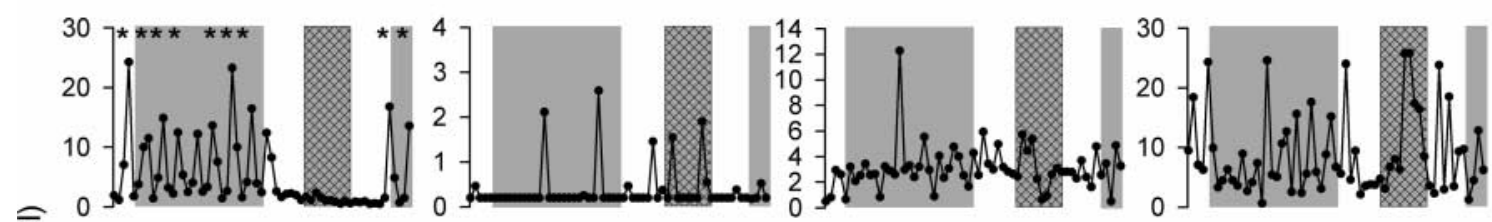

(ii)
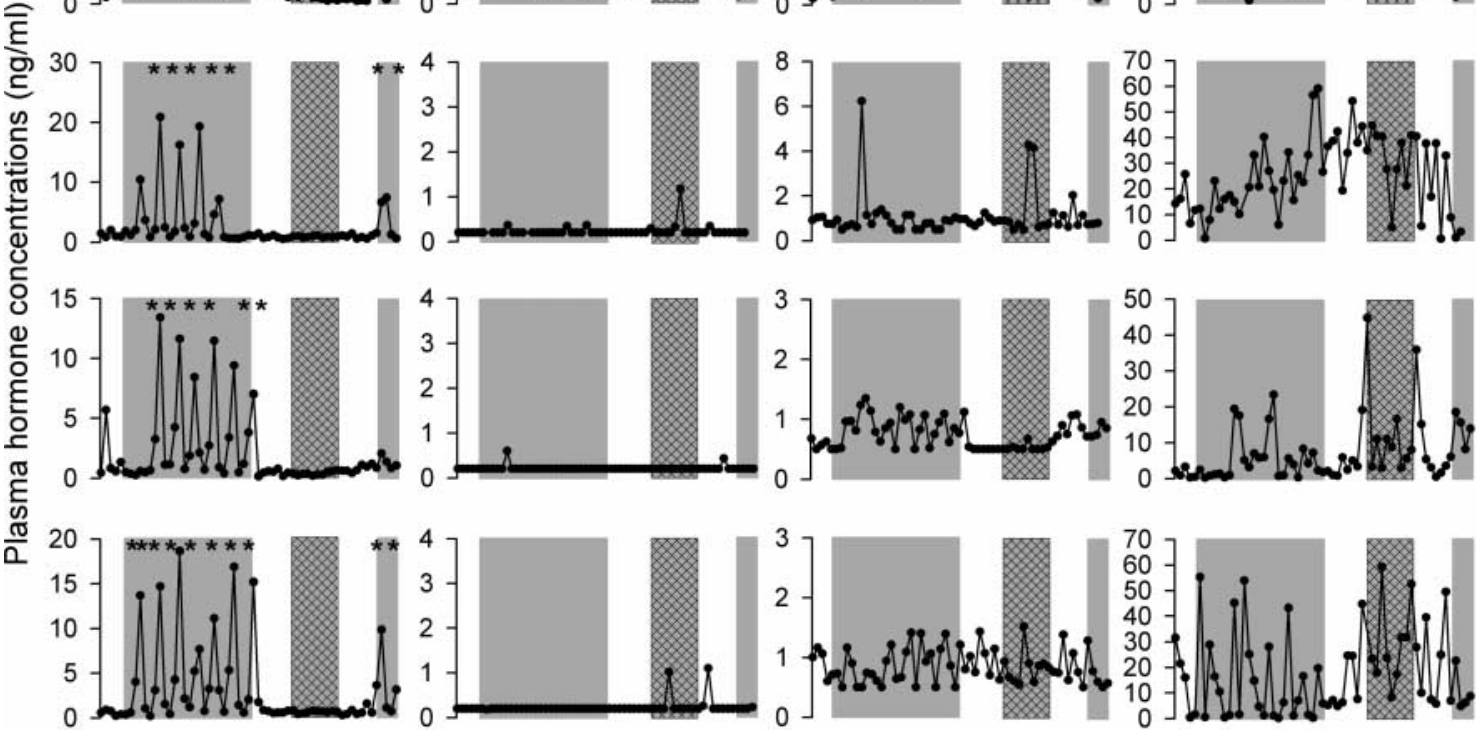

(iv)

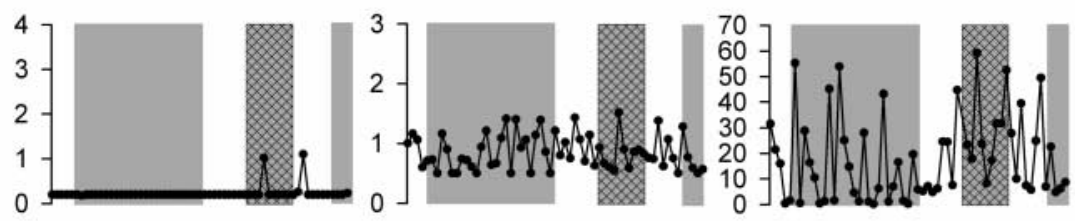

(v)

(vi)
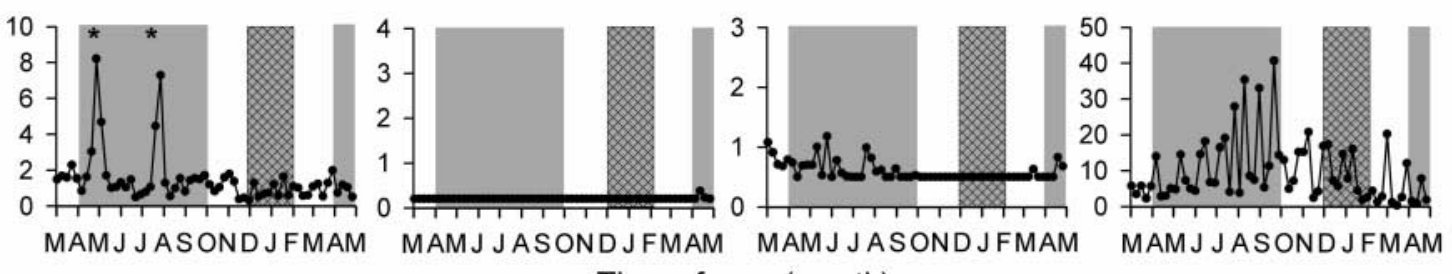

Time of year (month)

Figure 5 Weekly plasma concentrations of (a) P, (b) LH, (c) FSH and (d) Prl over 15 months incorporating the breeding (shaded areas) and non-breeding (shaded and hatched areas) seasons in individual adult female brushtail possums (i)-(vi) that were housed with vasectomised males. Analysis of these results included data from April to October (entire breeding season 2004), December to February (non-breeding season) and April to May (partial breeding season 2005). The non-shaded areas were considered the transition time between the breeding and non-breeding seasons and were excluded from analysis. Asterisks indicate the day when an increase in epithelial cells was first detected in the urine of individual possums.

Significant mean plasma concentrations of Prl were present only after the 'switch-phase' at 13-17 weeks of lactation. This phase coincided with the development of homeostasis of the pouch young, growth of fur, opening of the eyes and everincreasing periods of emergence from the pouch, as well as changes in suckling intensity and frequency and in milk composition (Cowan 1989, Crisp et al. 1989, Bird et al. 1994, Nicholas et al. 1997, Demmer et al. 1998, Rose et al. 2003). In the present study, the levels of Prl were markedly elevated for a much shorter period (i.e. $\sim 6$ weeks) compared to approximately 11 weeks in a previous report (Hinds \& Janssens 1986). This difference is likely to be due to the lactational profile being the integration of a series of truncated data from different possums in the Hinds \& Janssens study. Elevated Prl concentrations during the later stages of lactation are, at least in part, under dopaminergic control in the brushtail possum (Crawford et al. 2005), Bennett's wallaby (Curlewis et al. 1986) and Tasmanian bettong (Rose et al. 1996). In eutherians, suckling decreases dopamine input to the thyrothroph cells of the anterior pituitary gland resulting 


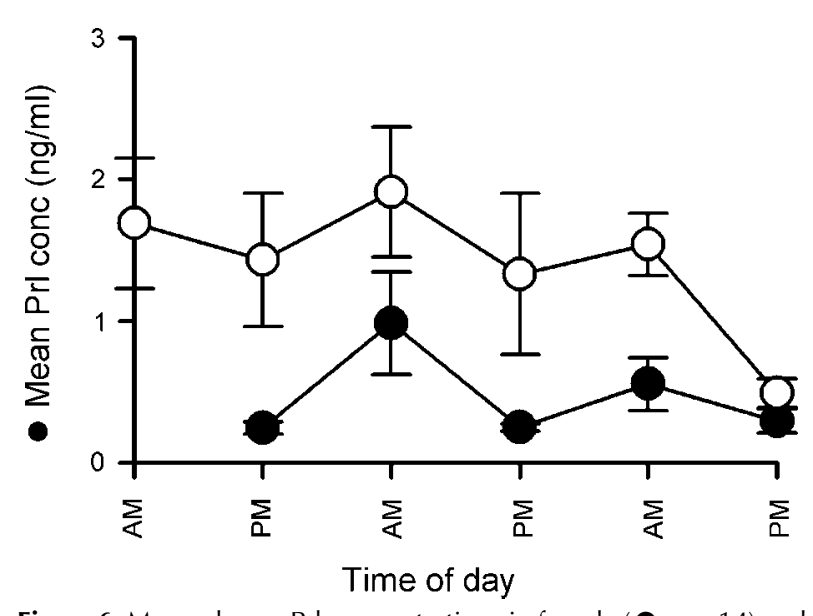

Figure 6 Mean plasma Prl concentrations in female $(\boldsymbol{O} ; n=14)$ and male $(\bigcirc ; n=8-11)$ possums at either $0800 \mathrm{~h}$ or $1700-2000 \mathrm{~h}$ over three consecutive days. Values are denoted as means \pm s.E.M.

in hyperprolactinaemia (Ben- Jonathan et al. 1980). Although this mechanism is not well understood, a reduced activity of the tuberoinfundibular dopaminergic neurons was associated with a reduction in tyrosine hydroxylase gene expression through a direct feedback mechanism via the activation of the neural afferents that extend from the nipple to the hypothalamus (Wang et al. 1993, Li et al. 1999, Berghorn et al. 2001). Communication between the pituitary and mammary glands is probable in the brushtail possum considering that sensitivity to oxytocin, a pituitary-derived hormone responsible for the effective 'let-down' of milk from the mammary gland (Cross 1977), was marked in small mammary glands supporting immature pouch young compared with larger ones in this species and was facilitated through increased concentration of oxytocin receptors (Sernia et al. 1991). However, perhaps the newly born, immature and immune-deficient (Deane \& Cooper 1984, Adamski \& Demmer 2000, Adamski et al. 2000) pouch young is incapable of suckling at an intensity required to elicit an increase in Prl concentrations during the first 13 weeks of lactation, and that hyperprolactinaemia is only necessary for facilitation of larger quantities and/or change in composition of milk that is required to support the older joey ( $>13$ weeks old). In this study, elevations in Prl concentrations in the later stages of lactation were not observed in animals that had pouch young either die or be removed due to illness. Whether the young were compromised due to deficiencies of the mother (suppressed Prl concentrations) or the joey (inability to suckle) is unknown.

Preparturition events do not appear fundamental to the initiation nor the maintenance of lactation since the attachment of newborn pouch young to teats of nonmated, as well as virgin, female brushtail possums resulted in milk production and subsequent survival and normal growth of transplanted pouch young (Sharman 1962). It may be that the early stages of lactation are partly or wholly under local autocrine control through feedback inhibition by a milk protein. In ruminants, milk production is regulated via an autocrine mechanism whereby an inhibitory milk protein is synthesised and secreted in milk and acts in a concentrationdependent and reversible manner (Hendry et al. 1998). Additionally, alteration in the sucking pattern of young does not influence the milk composition or the rate of milk production in the Tammar wallaby (Nicholas et al. 1997, Trott et al. 2003). Collectively, these studies suggest that, while the marsupial pouch young is capable of initiating mammogenesis and lactogenesis, it is the lactating adult that regulates both changes in milk composition and rate of milk production thereafter, and consequently the development and growth of the pouch young.

Whilst there is a distinct pattern of secretion of other pituitary-derived hormones (i.e. LH and FSH) during the follicular phase in the brushtail possum (Crawford et al. 1999, this study), there was no obvious discrete profile of $\operatorname{Prl}$ secretion during this time. A distinct preovulatory biphasic surge of Prl was observed in three out of four possums in which a typical preovulatory LH surge was detected. However, a biphasic preovulatory surge of Prl was absent in one animal that exhibited a characteristic preovulatory $\mathrm{LH}$ surge and, several days later, a postovulatory rise in $\mathrm{P}_{4}$ concentration, suggesting normal functioning of the CL. From these varied results, it is difficult to conclude that the preovulatory Prl surge is a fundamental event in the late follicular stage in this species. It is interesting to note that Prl secretion appeared to be tightly regulated prior to and immediately after the preovulatory surges in all possums in this study. In rats, ovulation is also preceded by a Prl surge and the onset of this surge usually precedes the onset of the preovulatory LH surge by $2-4 \mathrm{~h}$ (Wuttke \& Meites 1970, Butcher et al. 1974, Hirsch et al. 1993). The preovulatory Prl surge in rats has luteotrophic and luteolytic effects in that it causes augmentation of LH-induced luteinisation and associated increased $\mathrm{P}_{4}$ secretion (Butcher et al. 1972, Döhler \& Wuttke 1974, Morishige \& Rothchild 1974), as well as regression of old CLs (Malven \& Sawyer 1966, Wuttke \& Meites 1971) through stimulation of collagenases (Hirsch et al. 1999). Blockage of the preovulatory Prl surge by dopaminergic agents in rats did not disturb oestrus cyclicity and ovulation (Döhler \& Wuttke 1974), but did result in the accumulation of non-steroidogenic CLs (Wuttke \& Meites 1971, Döhler \& Wuttke 1974). Regulation of the mechanism(s) involved in the generation of Prl surges is reported to be influenced by steroid hormones, and repeated cyclic steroid hormone replacement (oestradiol; $\mathrm{E}_{2}+\mathrm{P}_{4}$ ) was capable of producing Prl surges in ovariectomised 6-week-old rats, with multiple cycles resulting in a greater secretory response (Brown et al. 2004). In the possum, the follicular phase of the oestrous cycle is prolonged compared to that in the rat and regression of the latest CL was observed prior to the preovulatory $\mathrm{Prl}$ surge, suggesting that this surge may only exert luteotrophic effects in this species. 
Changes in photoperiod provide the principal environmental cue to annual reproductive cycles and are exerted on the suprachiasmatic nucleus (rhythm control centre) through the action of melatonin (Lincoln \& Short 1980). Melatonin is secreted during darkness and is thought to entrain the organism to the light-darkness changes of the environment. Melatonin acts in the mediobasal hypothalamus to modulate pulsatile gonadotrophin-releasing hormone secretion (Lincoln \& Maeda 1992, Malpaux et al. 1993) through the modification of the negative $\mathrm{E}_{2}$ feedback mechanism, as well as driving the distinct annual rhythms of Prl secretion (Lincoln \& Clarke 1994) in seasonal mammals. Specifically, Prl secretion peaks during the summer months (long day length) and reaches a nadir in the winter months (short day length) in sheep (Lincoln \& Short 1980), deer (Schulte et al. 1980, 1981), cattle (Koprowski \& Tucker 1971, Karg \& Shams 1974) and Tammar wallaby (Tyndale-Biscoe \& Hinds 1984, Hinds \& Tyndale-Biscoe 1985), but not in the Bennett's wallaby (Curlewis et al. 1986, Brinklow \& Loudon 1993). We report in this study a similar pattern of seasonal Prl secretion in the female brushtail possum. However, evidence in sheep and deer suggests that Prl is not the mediator of the breeding season, or other functions under seasonal control such as voluntary food intake, body weight, wool growth and pelage changes (Milne et al. 1990, Curlewis et al. 1991). Although reproductive cyclicity is evident in the brushtail possum, commencing during decreasing day length and terminating during increasing day length (Smith et al. 1969, Crawley 1973, Kearle 1984, Cowan 1990, McLeod et al. 1999), there is no evidence of a role of $\mathrm{Prl}$ in the regulation of seasonal breeding in this, or any marsupial species. Additionally, administration of bromocriptine (dopamine agonist) resulted in reactivation of the suppressed CL and resumption of the development of the quiescent embryo and subsequent birth in the female Tammar wallaby during lactational, but not seasonal, anoestrous (Tyndale-Biscoe \& Hinds 1984).

Daily changes in melatonin secretion also result in a prominent circadian rhythm of Prl secretion in the ram during long days; however, the timing of this cycle shifted and the rate of secretion diminished after exposure to short days (Lincoln \& Short 1980). Similarly, there is a nocturnal rise in Prl in man (Arendt 1988, Thorner et al. 1992) although some studies have attributed this to the occurrence of sleep rather than the concomitant elevation in melatonin levels (Sassin et al. 1973). Whilst this study did not include intensive sampling to elucidate the precise circadian rhythm of $\mathrm{Prl}$ secretion in male possums, the elevated morning and nadir afternoon levels in both female and male possums suggested that one exists in this species.

In conclusion, measurement of plasma Prl concentrations during lactation in the brushtail possum revealed a short period ( 6 weeks) of elevation in the later stages, whilst concentrations were low during early lactation suggesting that either $\operatorname{Prl}$ is not essential for galactopoiesis or that sensitivity of the mammary gland to Prl is markedly enhanced during the early stages of lactation. We also report a distinct biphasic preovulatory Prl surge, which is unlikely to be involved in luteolysis, but may exert luteotrophic effects in this species although this remains to be determined. Finally, the characteristic circannual and circadian patterns of $\mathrm{Prl}$ secretion observed in many mammalian seasonal breeders was also observed in the brushtail possum in this study, but the role of $\mathrm{Prl}$ in the regulation of seasonality in this species is unknown.

\section{Acknowledgements}

The authors would like to thank Dr Bryce Buddle for performing the vasectomies and Brigitta Mester, Jolene Hay, Kirsty Simpson and Dr Gail Shuttleworth for excellent animal handling and technical expertise. The authors would also like to thank Prof. Alan S McNeilly for the generous gift of M91 $\mathrm{hFSH} \beta$ antiserum and Prof. Kenneth P McNatty for a helpful critique of the manuscript.

\section{Funding}

This research was supported by grants from the Foundation of Research, Science and Technology and MAF Policy, New Zealand. There is no conflict of interest that would prejudice the impartiality of this study.

\section{References}

Adamski FM \& Demmer J 2000 Immunological protection of the vulnerable marsupial pouch young: two periods of immune transfer during lactation in Trichosurus vulpecula (brushtail possum). Developmental and Comparative Immunology 24 491-502.

Adamski FM, King AT \& Demmer J 2000 Expression of the Fc receptor in the mammary gland during lactation in the marsupial Trichosurus vulpecula (brushtail possum). Molecular Immunology 37 435-444.

Albarracin CT, Parmer TG, Duan WR, Nelson SE \& Gibori G 1994 Identification of a major prolactin-regulated protein as $20 \alpha$-hydroxysteroid dehydrogenase: coordinate regulation of its activity, protein content and messenger ribonucleic acid expression. Endocrinology 134 2453-2460.

Arendt J 1988 Melatonin. Review. Clinical Endocrinology 29 205-229.

Bartke A 1980 Role of prolactin in reproduction in male mammals. Federation Proceedings 39 2577-2581.

Ben-Jonathan N, Neill MA, Arbogast LA, Peters LL \& Hoefer MT 1980 Dopamine in hypophysial portal blood: relationship to circulating prolactin in pregnant and lactating rats. Endocrinology 106 690-696.

Berghorn KA, Le WW, Sherman TG \& Hoffman GE 2001 Suckling stimulus suppresses messenger RNA for tyrosine hydroxylase in arcuate neurons during lactation. Journal of Comparative Neurology 438 423-432.

Bird PH, Hendry KAK, Shaw DC, Wilde CJ \& Nicholas KR 1994 Progressive changes in milk protein gene expression and prolactin binding during lactation in the tammar wallaby (Macropus engenii). Journal of Molecular Endocrinology 13 117-125.

Bole-Feysot C, Goffin V, Edery M, Binart N \& Kelly PA 1998 Prolactin (Prl) and its receptor: actions, signal transduction pathways and phenotypes observed in Prl receptor knockout mice. Endocrine Reviews 19 225-268.

Brinklow BR \& Loudon ASI 1993 Evidence for a circannual rhythm of reproduction and prolactin secretion in a seasonally breeding macropodid marsupial, the Bennett's wallaby (Macropus rufogriseus rugogriseus). Journal of Reproduction and Fertility 98 625-630. 
Brown AM, Janik JM, Murphree ES, King R \& Callahan P 2004 Effects of cyclic steroid hormone replacement on prolactin and luteinizing hormone surges in female rats. Reproduction 128 373-378.

Butcher RL, Fugo NW \& Collins WE 1972 Semicircadian rhythm in plasma levels of prolactin during early gestation in the rat. Endocrinology $901125-1129$.

Butcher RL, Collins WE \& Fugo NW 1974 Plasma concentration of LH, $\mathrm{FSH}$, prolactin, progesterone, and estradiol $17 \beta$ throughout the 4-day estrous cycle. Endocrinology 94 1704-1708.

Costello LC \& Franklin RB 1994 Effect of prolactin on the prostate. Prostate 24 162-166.

Cowan PE 1989 Changes in milk composition during lactation in the common brushtail possum, Trichosurus vulpecula (Marsupialia:Phalangeridae). Reproduction, Fertility and Development 1 325-335.

Cowan PE 1990 Brushtail possum. In The Handbook of New Zealand Mammals, pp 67-98. Ed CM King. Oxford, UK: Oxford University Press.

Crawford JL, Shackell GH, Thompson EG, McLeod BJ \& Hurst PR 1997 Preovulatory follicle development and ovulation in the brushtail possum (Trichosurus vulpecula) monitored by repeated laparoscopy. Journal of Reproduction and Fertility 110 361-370.

Crawford JL, McLeod BJ, Thompson EG, Hurst PR, Colbourne LE, Lun S \& Eckery DC 1999 Plasma gonadotropin concentrations in the cyclic female brushtail possum (Trichosurus vulpecula). General and Comparative Endocrinology 116 73-80.

Crawford JL, Lun S, Demmer J \& Eckery DC 2005 Prolactin in the brushtail possum (Trichosurus vulpecula): Development of homologous radioimmunoassay using recombinant possum prolactin. General and Comparative Endocrinology 142 297-307.

Crawley MC 1973 A live-trapping study of Australian brush-tailed possums, Trichosurus vulpecula (Kerr), in the Orongaronga valley, Wellington, New Zealand. Australian Journal of Zoology 21 75-90.

Crisp EA, Cowan PE \& Messer M 1989 Changes in milk carbohydrates during lactation in the common brushtail possum Trichosurus vulpecula (Marsupialia: Phalangeridae). Reproduction, Fertility and Development 1 309-314.

Cross BA 1977 Comparative physiology of milk removal. Symposium of the Zoological Society of London 41 193-210.

Curlewis JD, Axelson M \& Stone GM 1985 Identification of the major steroids in ovarian and adrenal venous plasma of the brush-tail possum (Trichosurus vulpecula) and changes in the peripheral plasma levels of oestradiol and progesterone during the reproductive cycle. Journal of Endocrinology 105 53-62.

Curlewis JD, White AS, Loudon ASI \& McNeilly AS 1986 Effects of lactation and season on plasma prolactin concentrations and response to bromocriptine during lactation in the Bennett's wallaby (Macropus rufogriseus rufogriseus). Journal of Endocrinology 110 59-66.

Curlewis JD, Sibbald AM, Milne JA \& McNeilly AS 1991 Chronic treatment with long-acting bromocriptine does not affect duration of the breeding season, voluntary food intake, body weight, or wool growth in the Scottish Blackface ewe. Reproduction, Fertility and Development 3 25-33.

Deane EM \& Cooper DW 1984 Immunology of pouch young marsupials. I. Levels of immunoglobulin, transferrin and albumin in the blood and milk of euros and wallaroos (hill kangaroos: Macropus robustus, Marsupialia).

Developmental and Comparative Immunology 8 863-867.

Demmer J, Ross IK, Ginger MR, Piotte CP \& Grigor MR 1998 Differential expression of milk protein genes during lactation in the common brushtail possum (Trichosurus vulpecula). Journal of Molecular Endocrinology 20 37-44.

Döhler KD \& Wuttke W 1974 Total blockade of phasic pituitary prolactin release in rats: effects of serum $\mathrm{LH}$ and progesterone during the estrous cycle and pregnancy. Endocrinology 94 1595-1600.

Duckworth JA, Scobie S, Jones DE \& Selwood L 1998 Determination of oestrus and mating in captive female brushtail possums, Trichosurus vulpecular (Marsupialia: Phalangeridae), from urine samples. Australian Journal of Zoology 46 547-555.

Eckery DC, Juengel JL, Whale LJ, Thomson BP, Lun S \& McNatty KP 2002 The corpus luteum and interstitial tissue in a marsupial, the brushtail possum (Trichosurus vulpecula). Molecular and Cellular Endocrinology 191 81-87.
Freeman ME, Kanyicska B, Lerant A \& Nagy G 2000 Prolactin: structure, function and regulation of secretion. Physiological Reviews 80 1523-1631.

Gibori G 1993 The corpus luteum of pregnancy. In The Ovary, pp 261-317. Eds E Adashi \& PC Leung. New York: Raven Press.

Hearn JP 1974 The pituitary gland and implantation in the tammar wallaby, Macropus engenii. Journal of Reproduction and Fertility 39 235-241.

Hendry KAK, Simpson KJ, Nicholas KR \& Wilde CJ 1998 Autocrine inhibition of milk secretion in the lactating tammar wallaby (Macropus engenii). Journal of Molecular Endocrinology 21 169-177.

Hinds LA \& Tyndale-Biscoe CH 1985 Seasonal and circadian patterns of circulating prolactin during lactation and seasonal quiescence in the tammar, Macropus engenii. Journal of Reproduction and Fertility 74 173-183.

Hinds LA \& Janssens PA 1986 Changes in prolactin in peripheral plasma during lactation in the brushtail possum Trichosurus vulpecula. Australian Journal of Biological Science 39 171-178.

Hinds LA \& Merchant JC 1986 Plasma prolactin concentrations throughout lactation in the eastern quoll, Dasyurus viverrinus (Marsupialia:Dasyuridae). Australian Journal of Biological Science 39 179-186.

Hirsch B, Leonhardt S, Jarry H, Reich R, Tsafriri A \& Wuttke W 1993 In vitro measurement of rat ovarian collagenolytic activities. Endocrinology 133 2761-2765.

Hirsch B, Knoke I, Leonhardt S, Pitzel L, Jarry H \& Wuttke W 1999 Stimulation of matrix-metalloproteinase-1 and tissue inhibitor of metalloproteinase- 1 gene expression in rats by the preovulatory prolactin peak. European Journal of Endocrinology 140 583-589.

Karg H \& Shams D 1974 Prolactin release in cattle. Journal of Reproduction and Fertility 39 463-472.

Kearle JA 1984 Variation in the ecology of Trichosurus: Its adaptive significance. In Possums and Gliders, pp 483-499. Eds AP Smith \& ID Hume. Sydney, Australia: Australian Mammal Society.

Kelly PA, Djiane J, Postel-Vinay MC \& Edery M 1991 The prolactin/growth hormone receptor family. Endocrine Reviews 12 235-251.

Koprowski JA \& Tucker HA 1971 Prolactin and growth hormone circadian periodicity in lactating cows. Proceedings of the Society for Experimental Biology and Medicine 140 1012-1014.

Li C, Chen P \& Smith MS 1999 Neuropeptide Y and tuberoinfundibular dopamine activities are altered during lactation: role of prolactin. Endocrinology 140 118-123.

Lincoln GA \& Short RV 1980 Seasonal breeding: nature's contraceptive. Recent Progress in Hormone Research 36 1-51.

Lincoln GA \& Maeda KI 1992 Reproductive effects of placing microimplants of melatonin in the mediobasal hypothalamus and preoptic area in rams. Journal of Endocrinology 132 201-215.

Lincoln GA \& Clarke IJ 1994 Photoperiodically-induced cycles in the secretion of prolactin in hypothalamo-pituitary disconnected rams: evidence for translation of the melatonin signal in the pituitary gland. Journal of Neuroendocrinology 6 251-260.

Malpaux B, Daveau A, Maurice F, Gayrard V \& Theiry JC 1993 Short days effects of melatonin on luteinizing hormone secretion in the ewe: evidence for central sites of action in the mediobasal hypothalamus. Biology of Reproduction 48 752-760.

Malven PV \& Sawyer CH 1966 A luteolytic action of prolactin in hypophysectomized rats. Endocrinology 79 268-274.

McLeod BJ, Thompson EG, Crawford JL \& Shackell GH 1997 Successful group housing of wild-caught brushtail possums (Trichosurus vulpecula). Animal Welfare 6 67-76.

McLeod BJ, Thompson EG \& Crawford JL 1999 Synchrony of onset and cessation of breeding activity in brushtail possums (Trichosurus vulpecula) in coastal Otago, New Zealand. Proceedings of the New Zealand Society of Animal Production 59 229-232.

Milne JA, Loudon AS, Sibbald AM, Curlewis JD \& McNeilly AS 1990 Effects of melatonin and a dopamine agonist and antagonist on seasonal changes in voluntary intake, reproductive activity and plasma concentrations of prolactin and tri-iodothyronine in red deer hinds. Journal of Endocrinology 125 241-249.

Moore LG, Ng Chie W, Lun S, Lawrence SB, Heath DA \& McNatty KP $1997 a$ Isolation, characterization and radioimmunoassay of luteinizing 
hormone in the brushtail possum. Reproduction, Fertility and Development 9 419-425.

Moore LG, Ng-Chie W, Lun S, Lawrence SB, Young W \& McNatty KP $1997 b$ Follicle-stimulating hormone in the brushtail possum (Trichosurus vulpecula): Purification, characterization, and radioimmunoassay. General and Comparative Endocrinology 106 30-38.

Morishige WK \& Rothchild I 1974 Temporal aspects of the regulation of corpus luteum function by luteinizing hormone, prolactin and placental luteotrophin during the first half of pregnancy in the rat. Endocrinology 95 260-274.

Muths E \& Hinds LA 1996 Circulating levels of prolactin and progesterone in a wild population of red kangaroos (Macropus rufus) Marsupialia: Macropodidae. General and Comparative Endocrinology 101 317-322.

Nicholas KR, Simpson KJ, Wilson M, Trott JF \& Shaw D 1997 The tammar wallaby: A model to study putative autocrine-induced changes in milk composition. Journal of Mammary Gland Biology and Neoplasia 2 299-309.

Rose RW, Jones SM \& Macfadyen AS 1996 Effects of bromocriptine on lactation and plasma progesterone in Bettongia gaimardi, a Tasmanian macropodid marsupial. Reproduction, Fertility and Development 8 1061-1067.

Rose RW, Morahan TM, Mulchay JE \& Ratkowsky DA 2003 Milk composition and growth in wild and captive Tasmanian bettongs, Bettongia gaimardi (Marsupialia). Journal of Comparative Physiology B 173 125-133.

Sassin JF, Frantz AG, Kapen S \& Weitzman ED 1973 The nocturnal rise of human prolactin is dependent on sleep. Journal of Clinical Endocrinology and Metabolism 37 436-440.

Schulte BA, Parsons JA, Seal US, Plotka ED, Verme LJ \& Ozoga JJ 1980 Heterologous radioimmunoassay for deer prolactin. General and Comparative Endocrinology 40 59-68.

Schulte BA, Seal US, Plotka ED, Letellier MA, Verme LJ, Ozoga JJ \& Parsons JA 1981 The effect of pinealectomy on seasonal changes in prolactin secretion in the white-tailed deer (Odocoileus virginianus borealis). Endocrinology 108 173-178.

Sernia C, Thomas WG \& Gemmell RT 1991 Oxytocin receptors in the mammary gland and reproductive tract of a marsupial, the brushtail possum (Trichosurus vulpecula). Biology of Reproduction 45 673-679.

Shah GV \& Sheth AR 1979 Is prolactin involved in sperm capacitation. Medical Hypotheses 5 909-914.

Sharman GB 1962 The initiation and maintenance of lactation in the marsupial, Trichosurus vulpecula. Journal of Endocrinology 25 375-385.

Sinha YN 1995 Structural variants of prolactin: Occurrence and physiological significance. Endocrine Reviews 16 354-369.
Smith MJ, Brown BK \& Frith HJ 1969 Breeding of the brushtailed possum, Trichosurus vulpecula Kerr in New South Wales. CSIRO Wildlife Research $\mathbf{1 4}$ 181-193.

Telleria CM, Parmer TG, Zhong L, Clarke DL, Albarracin CT, Duan WR, Linzer DIH \& Gibori G 1997 The different forms of the prolactin receptor in the rat corpus luteum: Developmental expression and hormonal regulation in pregnancy. Endocrinology 138 4812-4820.

Thomas K \& Capecchi M 1987 Site-directed mutagenesis by gene targeting in mouse embryo-derived stem cells. Cell 51 503-512.

Thorner MO, Vance ML, Horvath E \& Kovacs K 1992 The anterior pituitary. In Williams Textbook of Endocrinology, p 384. Eds JD Wilson \& DW Foster. Philadelphia: W.B. Saunders Company.

Trott JF, Simpson KJ, Moyle RLC, Hearn CM, Shaw G, Nicholas KR \& Renfree MB 2003 Maternal regulation of milk composition, milk production, and pouch young development during lactation in the tammar wallaby (Macropus engenii). Biology of Reproduction 68 929-936.

Tyndale-Biscoe CH \& Hinds LA 1984 Seasonal patterns of circulating progesterone and prolactin and response to bromocriptine in the female Tammar Macropus engenii. General and Comparative Endocrinology 53 58-68.

Wang HJ, Hoffman GE \& Smith MS 1993 Suppressed tyrosine hydroxylase gene expression in the tuberoinfundibular dopaminergic system during lactation. Endocrinology 133 1657-1663.

Whale LJ, Eckery DC \& Juengel JL 2003 Determination of steroidogenic potential of ovarian cells of the brushtail possum (Trichosurus vulpecula). Biology of Reproduction 69 947-958.

Wuttke W \& Meites J 1970 Effects of ether and pentobarbital on serum prolactin and LH levels in pro-oestrous rats. Proceedings of the Society for Experimental Biology and Medicine 135 648-652.

Wuttke W \& Meites J 1971 Luteolytic role of prolactin during the estrous cycle of the rat. Proceedings of the Society for Experimental Biology and Medicine 137 988-991.

Received 27 March 2006

Received in final form 1 May 2006

Accepted 4 May 2006

Made available online as an Accepted Preprint 11 May 2006 